\title{
PLANNING, ANALYSIS AND DESIGN OF SHOPPING MALL
}

\author{
Yuvaraj.S \\ Asst. prof, Department of Civil \\ Sri Eshwar College of engineering, Coimbatore, \\ Tamilnadu, India
}

\begin{abstract}
The project comprises of making PLANNING, ANALYSIS, DESIGN AND ESTIMATION OF SHOPPING COMPLEX AT COIMBATORE. The principle objective of this project is to plan, analyse and design shopping complex using AutoCAD, Revit Architecture and Staad Pro. The desing also involves manual calculation of structural components. The purpose building consists of basement parking, stilt+4 storey of total area . The building consists of various types of shops, trade offices, restaurants, etc. Thus we have provided all adequate features to our maximum level required for a shopping complex. We designed the building as a framed structure in limit state method for calculating beam moment both for safety and serviceability. The plinth area is about 39000sq.ft. This floor comprises of shops.First floor with or with various shops. Third floor is provided with shops, restaurants, food court, Play area,etc. Design of Structural components such as slabs, beams, columns, staircase, and footing are carried out as per IS: 456-2000.
\end{abstract}

\section{INTRODUCTION}

A building generally refers to a system of two or more connected parts use to support loads. It is an assemblage of two or more components to each other so that they serve to carry the loads developing due to the self-weight and super imposed load safely without causing any serviceability failure.

The building plan is drafted as per National Building Code of India 2016, the requirements and user convenience. Floor plans are drawn using AutoCAD. It is an overview of building that are yet to be constructed. Dimensions are drawn between the walls to specify the room sizes and wall lengths. Floor plan will also indicate rooms, all the doors and windows and any built-in elements, such as plumbing fixtures and cabinets, water heaters and furnaces, etc

Elevations are a non-perspective view of the buildings. These are drawn to scale so that measurements can be taken for any aspect necessary. Plans include front, rear and both

\author{
Vaishnavi.k, Mokeshprabhu.E, Ashok.s, Abijith.K \\ Department of Civil \\ Sri Eshwar College of engineering, Coimbatore, \\ Tamilnadu, India
}

side elevations. The elevation specify the details that are necessary to give the building its structure.

Once a preliminary design of a structure is fixed, the structure must be analyzed to make sure that it has required strength of rigidity, to design a structure and also certain idealization is to be made as to how the members are supported and connected together.

This building is located at Avinashi road, Coimbatore. The total area is 3,30,000sq.ft the safe bearing capacity of soil was estimated as $180 \mathrm{kN} / \mathrm{m}^{2}$. The type of building is planned for construction as RC framed structure. The grade of concrete is M20 \&that of steel is Fe 415 .

\section{METHODOLOGY}

Selection of Title

Literature study

Data collection from book

Planning using Autocad

Structural analysis using staad pro staadpro

Manual Design

Estimation

Results and discussion

Conclusion 


\section{International Journal of Engineering Applied Sciences and Technology, 2019 \\ Vol. 4, Issue 7, ISSN No. 2455-2143, Pages 169-172 \\ Published Online November 2019 in IJEAST (http://www.ijeast.com)}

\section{PLANNING ANALYSIS AND DESIGN}

\section{PLANNING}

This building is located at Gandhipuram, Coimbatore. The total area is 3,30,000sq.ft and the building area is $2,50,000$ sq.ft. The safe bearing capacity of soil was assumed as $180 \mathrm{kN} / \mathrm{m} 2$. The type of building is planned to construct as $\mathrm{RC}$ framed structure. The grade of concrete is taken as M20 and that of steel as Fe415.

Ground floor plinth area sq.ft. This floor comprises of shops. First floor with plinth area of 18500 sq.ft. The second floor is same as the first floor with various shops. Third floor is provided with shops, restaurants, food court, Play area, etc. The Design of Structural components such as slabs, beams, columns, staircase, and footing are carried out as per IS: 4562000.

As heavy load is imposed on the soil by the building, raft foundation is designed.

\section{GENERAL}

The analysis of the structure was carried out by using a software STAAD PRO. It is used for the purpose of analysis and design of structures. The activities involved in STAAD pro analysis are generation of model of the structure, applying the support conditions, applying member property for beam, column, slabs., applying various loads to the structure that are expected to act on it, and analyzing the structure.

\section{MODELLING OF STRUCTURE}

The structure was modelled as a frame. The nodes were fixed at required points followed by the adding of beams. Then the columns are drawn, and they were assigned in the footing level with fixed supports.

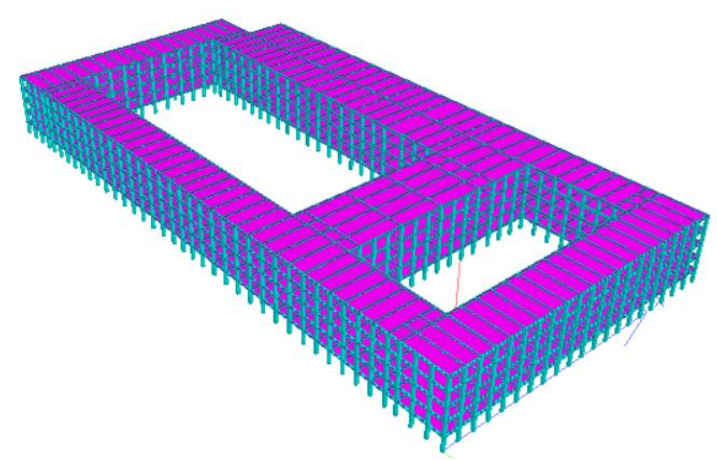

FIG 1 3D RENDERED MODEL

\section{MEMBER PROPERTY}

The property for the members were assigned as per requirements. The size of the beam, column, slab were fixed and assigned with concrete material with reinforcement

\section{APPLICATION OF LOADS}

The load that includes self-weight, brick wall load, floor load, seismic load, wind load was applied.

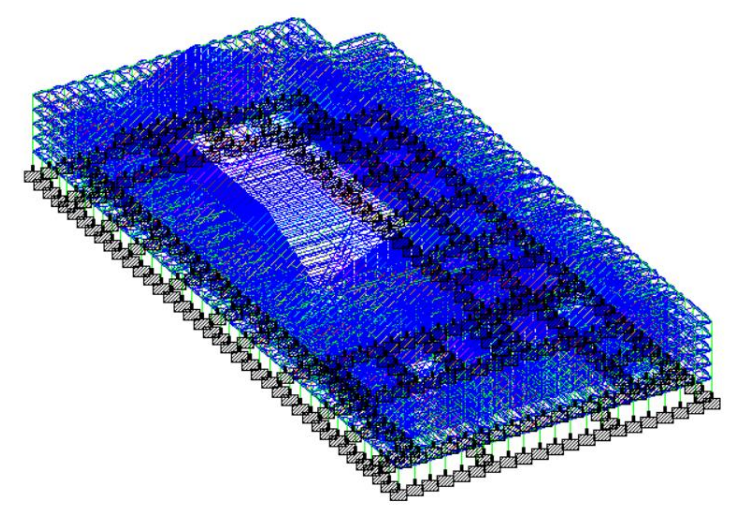

FIG 2 LIVE LOAD

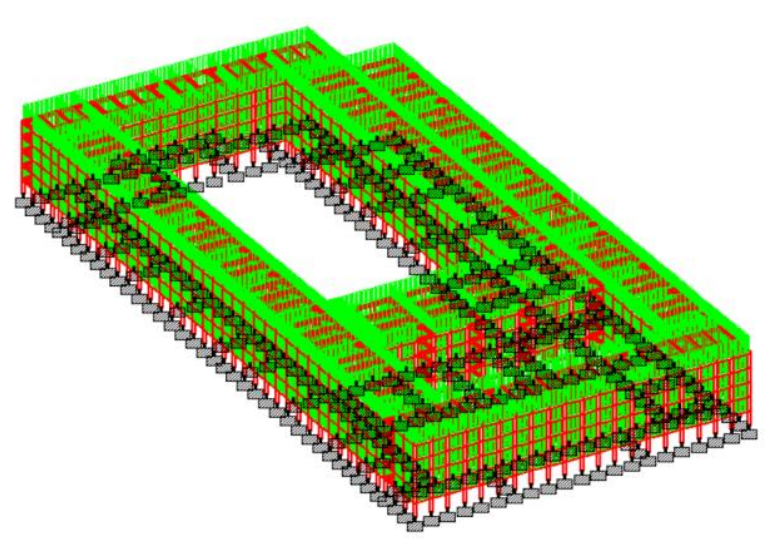

FIG 3 DEAD LOAD

After all the preliminary procedure, the structure was analyzed. The critical column, beam was taken for manual design to provide economical structure

\section{STAAD DESIGN}

The concrete design was performed was carried out in the STAAD Pro as per IS 456. It gives various results such as reinforcement specifications, weight of steel required for reinforcements, quantity of concrete required.

\section{DESIGN}

\section{GENERAL}

The basic objective in design is to produce a structure capable of resisting all applied loads without failure during its intended life. The structural design of any structure first involves establishing the loading and their design conditions, which must be supported by the structure and therefore must be considered its design. 


\section{DESIGN CODES}

In India, we use Indian Standard for the structural design of a building. In this project we have used IS 456-2000 and its design aid, IS 875-1987(Part I - Dead Load), IS 875-1987 (Part II- Live Load), and IS 875-1987 (Part III - Wind Load).

\section{DESIGN OF STRUCTURE}

The design of this structure involves,
a) One-way slab
b) Two-way slab
c) Doubly Reinforced beam
d) Axially Loaded Column
e) Uni-axially Loaded Column
f) Bi-axially Loaded Column
g) Raft Foundation
h) Dog Legged Staircase
Underground Water Tank
j) Design of Roof
k) Shear wall

\section{EXPERIMENT AND RESULT}

\section{PLAN}

For the comfort of the customers, we have provided enough shops, recreational facilities, office for trade, restaurants to satisfy their needs at one stop. The total area of 3,30,000 square feet is provided. The design of structural components such as slab, beam, column, staircase, shear wall, footing, and roof are carried out as per IS 456:2000.

\section{ANALYSIS}

After placing the nodes, beams and columns are provided, giving support to the building. Load cases are applied as per IS 875 1987. The loads applied are seismic load, dead load, live load, wind load and combination of these loads are provided. Then the structure is analyzed for the output/results. Dead load is assigned to the building referring IS 875 Part I, Live load is assigned to the assembly building by referring to IS 875 Part II, Wind Load is assigned to the building based on IS 875 Part III For the report of analysis, the critical beam is chosen by identifying the maximum deflection occurring in the beam, the critical column is taken by verifying the maximum load in the column.

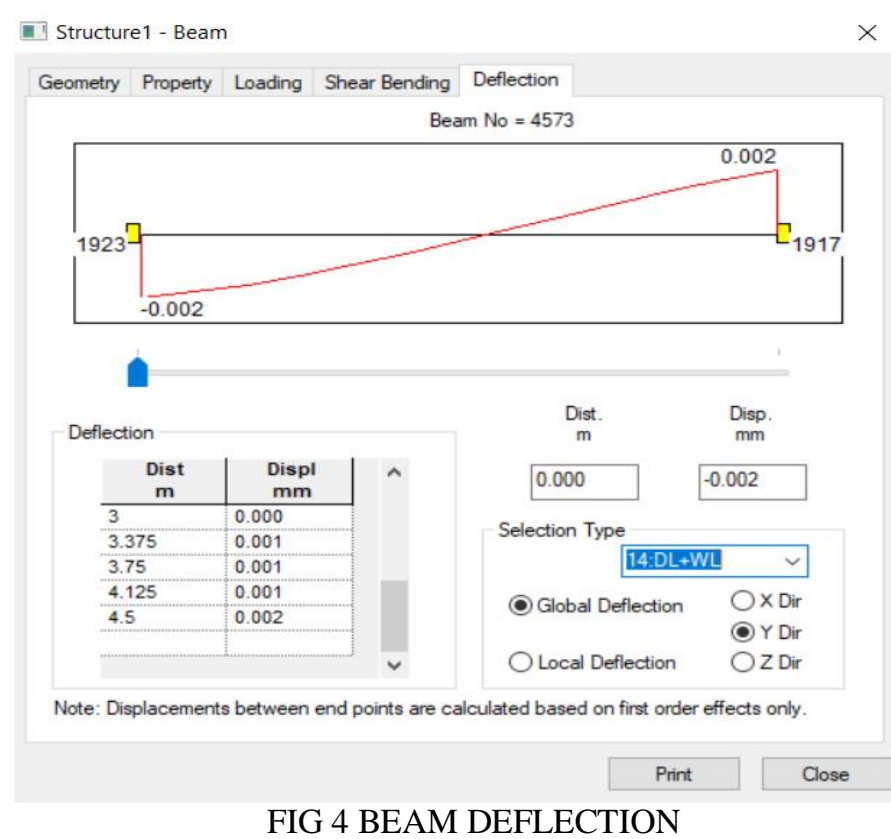

\section{DESIGN}

The design has been carried out for One-way slab, Two-way slab, Doubly Reinforced Beam, axially loaded column, Uniaxially loaded column, Bi-axially loaded column, Raft foundation, Dog Legged Staircase, Underground water tank, Roof, Shear wall. Due to heavy loads from the column, the design of raft footing has been carried out for this project.

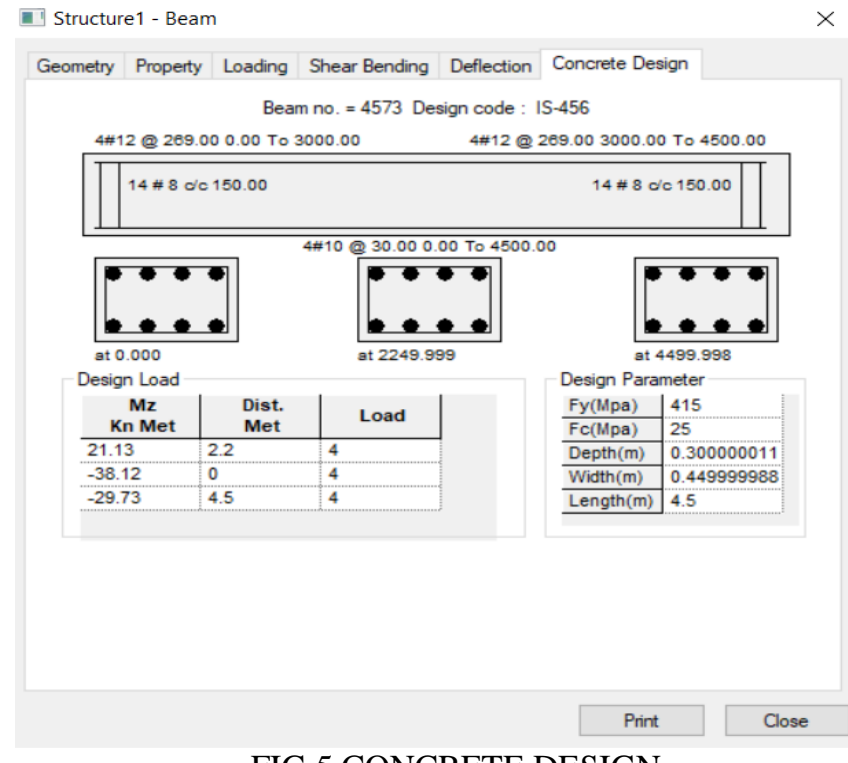




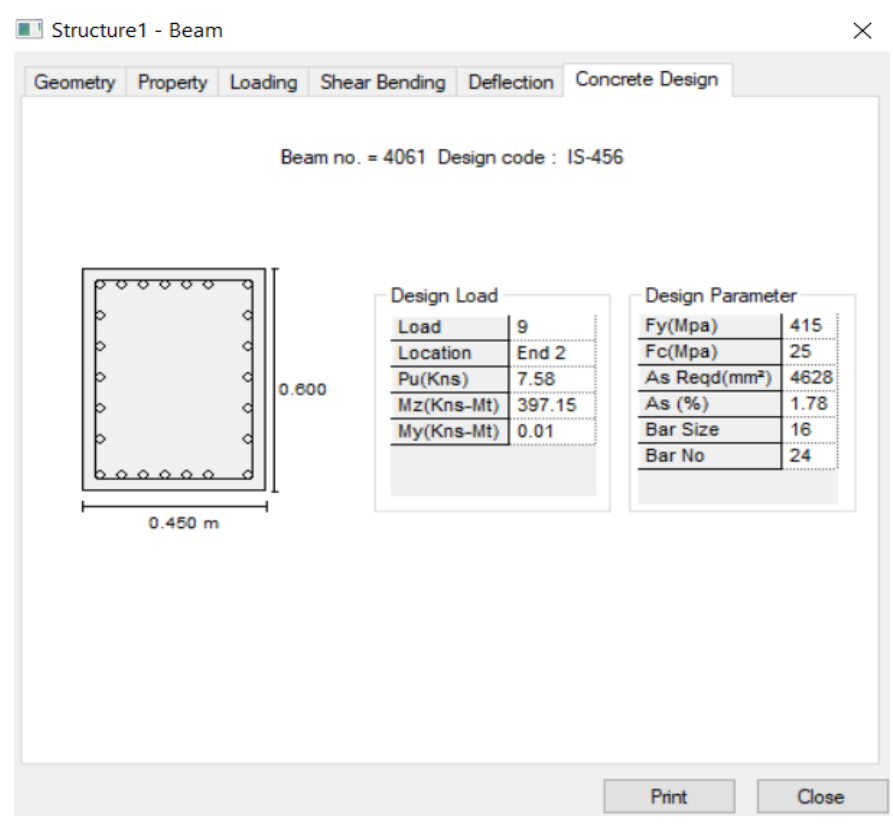

FIG 6 COLUMN DESIGN

\section{CONCLUSION}

In this project "Planning Analysis and Design of Shopping Complex at Gandhipuram" has been successfully completed. It is a Basement parking, G+4 storey building and total area of about 1,52,000 sq.ft. Thus the structure has been analyzed and designed using STAAD.Pro. Manual designing of elements have also been done. The verification of results was done by both graphically and numerically. The planning has been done for the Shopping Complex using AutoCAD for basement floor, ground floor, first floor, second floor, third \& fourth floor have been provided. The various structural elements such as foundation, staircase and footing were designed as per IS: 456-2000 in limit state method using M30 grade of concrete and Fe415 HYSD bars. The structural elements such as beams, columns and connections were designed s per provisions of IS: 875-1987. The design which was obtained through manual calculations was approximate to the values obtained through the analysis. Hence the building is safe.

\section{REFERENCE}

1. Mr. Gaurav Pandey, Mr. Sagar Jamle June-2016 OPTIMUM LOCATION OF FLOATING COLUMN IN MULTISTORY BUILDING WITH SEISMIC LOADING International Research Journal of Engineering and Technology (IRJET) Volume: 03 Issue: 06

2. K. Mounika Reddy, Mohd Zohair 2018 ANALYSIS AND DESIGN OF MULTISTOREY BUILDING

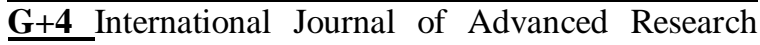

Ideas and Innovations in Technology (IRJET) Volume: 04 Issue: 01

3. Sarpreet Dadra, Prof. Manoharan Rajalingam, Dr. V. Rajesh Kumar 2018 ANALYSIS OF MULTISTOREY FRAMES FOR VARIOUS LOADING International Journal of Advance Research in Science and Engineering - volume 7issue no.3

4. R. O. Rahmon, K. K. Abdulraheem, A. A. Adelowo S. A. Raji March 2017 DESIGN OF A COMPOSITE TRUSS SYSTEM IN MULTISTOREY BUILDING Journal of Multidisciplinary Engineering Science and Technology (JMEST)ISSN: 2458-9403 Vol. 4 Issue

5. Amit Joshi, Murtaza Safdari JULY 2018 SEISMIC ANALYSIS OF A MULTI STOREY BUILDING HAVING FLOATING COLUMNS International Journal of Engineering Sciences and Research Technology

6. Nasreen, M.Khan March 2016 ANALYSIS AND DESIGN OF APPARTMENT BUILDING IJISET Vol 3 Issue 3

7. Sonia Longjam, S. Aravindhan April 2014 \begin{tabular}{llll} 
ANALYSIS & AND & DESIGN & OF \\
\hline
\end{tabular} SHOPPING MALL AGAINST LATERAL FORCES IJESI ISSN Vol 3 Issue 4

8. Abhay Guleria MAY 2014 STRUCTURAL ANALYSIS OF A MULTISTOREY BUILDING USING ETABS International Journal of Engineering Research \& Technology (IJERT) Vol. 3 Issue 5

9. IS 875-1987(Part I - Dead Load)

10. IS 875-1987 (Part II- Live Load)

11. IS 875-1987 (Part III - Wind Load)

12. IS 456-2000 and its design aid 